\title{
Constructing Occupational Identities: How Female Preschool Teachers Develop Professionalism
}

\author{
Mina Kim \\ Elementary Education, Graduate College of Education, San Francisco State University, 1600 Holloway Ave. BH 191, \\ San Francisco, CA 94132 \\ *Corresponding Author: minakim@sfsu.edu
}

Copyright (C) 2013 Horizon Research Publishing All rights reserved.

\begin{abstract}
This study explores how female teachers construct their occupational identities as teachers within early childhood education (ECE) settings. The combination of feminist scholarship and the use of teacher life history method allow these women to describe themselves as professionally trained and educated teachers who love teaching and children even though they are suffering from low pay and a generalized social image that preschool teachers are just "babysitters." These seven female teachers exhibited unique concept of professionalism: passion, dedication, and commitment to ECE field.
\end{abstract}

Keywords Early Childhood Education, Women Teacher, Professionalism, Identities, Feminism, Teacher Life History

\section{Introduction}

Teaching, particularly in preschool or primary grades, has been construed as an act of caring in American society. Biklen (1995) states that one primary teacher she knows often says, "We teach the child, not the subject." Love, care, and other nurturing behaviors are privileged attributes in preschool teaching contexts (Ayers, 1989; Goldstein, 1997; Biklen, 1995). One could even say that care is requisite or synonymous with primary teaching. This perception of preschool and primary grade teaching leads to early childhood education being characterized as babysitting, regardless of how teachers actually view themselves. ECE teachers often claim that teaching young children is not just providing care for young children, but also engaging children in learning through carefully constructed environments. Thus, they believed that being a preschool teacher is a professional job.

The term professional is defined in two ways (Spodek, Saracho, \& Peters, 1988): first, a professional earns a living by engaging in an occupation. Second, a professional is someone with a high degree of skill and competence in that occupation. Human service fields, like early childhood education, have made increased efforts toward professionalism through requiring higher levels of preparation and a higher degree of autonomy and self-regulation than currently exists in the field (Spodek, Saracho, \& Peters, 1988, p.7). Early childhood educators have put their efforts towards changing their image from baby sitters to professionals who develop curriculum and organize and deliver instruction (Saracho, 1993). This effort to adopt and to excel professionalism means that early childhood practitioners are trained not only for caring and nurturing children but also for engaging children in physical and cognitive development and managing the environments of young children systemically for education.

However, changing the roles and images of teachers from caregivers to curriculum developers was not necessarily a positive action. Before early childhood teacher education programs were included in higher education institutions, early childhood teachers were trained through craftsmanship (Spodek, et al, 1988). Although the use of the craftsmanship model was not an attempt to humiliate or lower the status of the field, professions did not always provide an appropriate model for training or practice in this field (Spodek, et al, 1988). As a result, the increased "professionalization" in this field was not welcomed or accepted by all.

From a feminist perspective, these contemporary roles and images of preschool teachers were the result of disregarding caregivers' roles as professionals. Because caring was considered women's natural ability in traditional society, this proposition has been a barrier for women teachers in becoming professionals, unlike their male colleagues. These professional images of teachers probably stem froma concept of professionalism that imposes masculine models of work and career advancement (Munro, 1998). Thus, caregivers were not regarded as professional in a patriarchal society, so educators and feminists tried to eliminate that role from early childhood education.

Nevertheless, since early childhood education has developed as a profession, the role of caregiver has become the fundamental requirement for qualifying preschool teachers in the early childhood educational field. Although early childhood education scholars have changed the term "caretakers" to "counselors/advisors" to suggest a 
professional image, the core meaning of this role is the same as "caregivers." Consequently, it is possible to speculate that the role of caregiver imposes biased images of preschool teachers as babysitters and results in constraining them from being professionals in a patriarchal society. Unfortunately, the image of preschool teachers as babysitters has changed little over the last century. As a result, female teachers themselves are still suffering from perceptions of the low status of professional knowledge in education, and from the lack of respect for, and control over, educational disciplines due to the very fact that this is a female dominated field that only "cares" for children (Goldstein,1997).

During the last decade and with the influence of feminism, western historians who called teaching a 'semi-profession' have shifted their emphasis from focusing on the limitations of professionals in female 'ghettos' to exploring the proto-feminist implications of "all-female" professions like nursing and social work and comparing them to male professions (Weiner \&Kallos, 2000). Thus, feminism, which encourages rethinking and redefining women in society, looks at female teachers and its teaching profession from different perspectives, but has rarely been applied to ECE. Feminist research does not blame women teachers for their socially and politically disadvantaged status relative to their male counterparts, but criticized socially prevalent patriarchal ideas. Feminist research presented that women started working in the ECE field, not because they were good at rearing children, but because they were guided to the field because they were women and mothers of children (Black, 1989; Coffey \&Delamont, 2000; Munro, 1998).

Educational researchers hasargued that women teachers are influenced by the professional, cultural, and historical contexts of the educational sector in which they are located, no matter where they work: either in the female-dominated preschool or the male-dominated gymnasium (Weiner \&Kallos, 2000). In this context, this study aims to interpret female ECE teachers' perceptions of their profession according to feminist perspectives, and focuses on the female teachers' own voices about these social and political issues related to their professionalism.

\section{Methodology}

As a means of understanding female teachers' occupational identities, a life history method was used to collect and analyze teachers' narratives. Scholars who support personal narrative and life history inquiries view these methods as vehicles for interpreting and understanding the nature and quality of teaching (Carter \& Doyle, 1996; Gubrium\& Holstein, 1997). Life history research methodology not only focuses on individual life stories, but also represents social, political and historical entities.Dhunpath (2000) believes that "writing biographies are indeed trivial pursuits, without a clear focus on this contextual intersection of life in relation to history, social science, education, feminist, and minority perspectives" (p.545-546). Biographies and other forms of life writing can enable the reconstruction and interpretation of subjectively meaningful features and critical episodes of a teacher educator's life within social and historical contexts. Moreover, life history methods allow readers to see the unities, continuities, discontinuities, images and rhythms of teachers' lives. From her point of view, the apparent value of this inquiry is clear: it allows educators to enter the subjects' lives and then understand their lives and work within broad social and political contexts.

This study employs feminist scholarship to analyze a way of understanding how feminist perspectives influence teachers and their actions as they think about their occupational identities. Little attention has been given to the gender issues of these teachers, despite the fact that the majority of teachers are female (Vuorikoski, 2001). Grumet (1981) notes that the sexual stereotyping and gendered occupational structures resulting from the rhetoric of "women's true profession" represents women teachers as objects of knowledge, and rarely as subjects. From a feminist point of view, studying the lives of women teachers' becomes a means of encouraging women teachers to reflect on their lives and educational experiences for the purposes of making explicit their taken-for-granted assumptions about education (Coffey \&Delamont, 2000; Munro, 1998). The term "feminization" of teaching not only means the gradual increase in the numbers and proportions of women teaching in most school systems, but also embodies female teachers' low status and payment within patriarchal systems (Acker, 1989; Prentice \&Theobald, 1991). Feminism has taught educators to explore the history of teachers from the point of view of the women who have taught school, and to perceive the structures that oppress women teachers within education (Middleton, 1989; Prentice \& Theobald, 1991). Little attention has been given to these teachers' gender issues, despite the fact that the majority of teachers are female (Vuorikoski, 2001). In the following, the process of data collection and analysis is described.

\subsection{Study Participants}

Seven female teachers were invited to participate in this study as a purposeful sample of preschool and kindergarten teachers. The seven female teachers taught full time in diverse types of preschools or kindergartens in a small, mid-western town where a large university was located. Recruiting preschool teachers required many considerations, because the nature of their age, generation, personal background, type of working environment, and teaching experience made remarkably different stories related to their identities and teaching practice. The ages of the teachers were between 23 and 60 years old, and so the range of their teaching experiences was wide: novice to 36 years. One teacher worked with kindergartners, five worked in the three to five multi-age groups, and one preschool teacher taught two- year-olds. In spite of efforts to represent diverse backgrounds of informants, their racial backgrounds were all 
European-American. The four childcare centers where the participants were working were located in the east part of town, which is a high-income area, and the rest of them were located inareas that were of relatively low income. In order to protect their privacy and confidentiality, the teachers are all referred to by pseudonyms.

\subsection{Data Collection}

Preliminary emails were used to establish their personal backgrounds, such as birthplace, college degree, the years of teaching experiences, and family background. The reason for distributing questions via email was to gain a sense of their life experience and to prepare follow-up questions to enrich our first interview.

Each of the teachers was interviewed three times and each interview lasted approximately one hour. All interviews were audiotaped and field notes were taken if needed. The three open-ended interviews of each teacher were organized around three areas: (1) personal life histories and occupational histories, (2) teaching practices and pedagogies, and (3) social perception about women as teachers. However, topics were often interwoven during the interviews, so it was impossible to keep one topic separated from another. Although teacher life history methodology invites teachers to tell their stories (Munro, 1998), in reality, few can easily talk about their life histories in front of a stranger. Therefore, ten guiding questions were developed to engage the teachers in telling their life histories, how they decided to become preschool teachers, and how they reflected upon their struggles or negotiations as female teachers within the context of social and educational difficulties. Yet, these questions were tentative because they were varied according to each teacher's story. Reviewing the previous interview transcript for each informant modified each set of interview questions used. Therefore, each interviewee had different emphases based on their own stories.

Observation was employed to discover how the revealed occupational identities of the female teachers were implemented into their everyday practice. I observed the seven teachers in their classrooms a total of three times each. The observations were usually made in the morning and scheduled in-between each interview. Thus, some questions and issues raised during observations were discussed later. Assuming that the participants were the best interpreters of their own actions and experiences, their comments and explanations were useful in understanding the relationships between their occupational identities and practice.

\subsection{Data Analysis}

The constant comparative method was used in data analysis (Glaser \& Strauss, 1975; Goodman, 1988b; Merriam, 2001). The interviews were transcribed verbatim,on a daily basis including pauses and laughter. The narrative analysis method employed for the present study used structural and deconstructive feminist perspectives to interpret and analyze data. Because this study focuses on finding female teachers' occupational identities constructed within a patriarchal values systems, the feminist perspective offers a powerful theoretical position to understand the formation process of female teacher's identities and how these identities are integrated into their classroom lives. The influence of recent feminist literary analysis has led to an interest in discourse and to a consciousness of the construction of historical texts as narratives open to interpretation and analysis, rather than simple reflections of a fact that happened in past (Weiler, 1992, p.39). From this perspective, applying the feminist discourse to this study provided a chance to reveal the problems and the struggle to create gendered selves of female teachers in their professions.

\section{Results}

The female preschool teachers in this study expressed their experience of dealing with an identity based on how the public looks at teachers of young children because preschool teachers' clients are the youngest children and preschool teachers are placed at the bottom of the ladder of the teaching profession (Goodman, 1988). As one way of gaining respect and professional status, a profession serves powerful groups of people in society (Lanier \& Little, 1986 cited in Goodman, 1988 , p. 45). From this perspective, teachers serving children-- a powerless group in society-- have few opportunities to build effective and prestigious relationships with powerful groups of people (Goodman, 1988). Moreover, even within the teaching profession where the work is reasonably similar for men and women, female teachers predominated in the lower grades and males in the higher grades (Carter, 2002).All participants of this study related in that they are not seen as "teachers" in many social situations.

\subsection{Teacher Roles Babysitting vs. Facilitators}

The female teachers in this study suffered predominantly from the social babysitter image. Even parents sometimes assumed that preschool teachers were not much different from babysitters; making it so the female preschool teachers encountered many cases that made them feel like babysitters. Grace, who ran her own family daycare center, was often faced with parents who assume that she is babysitting:

Last time, I met a parent who used to send his children to my daycare center. He asked me, "Are you still babysitting?" Gosh. so, I said to him strongly, "I've never babysat, and I will not. I just provide a quality care for children at my home." But, you know, they (people and parents) don't understand what early childhood education is. That's why they think we are babysitters. I think we need to get people involved to change people's conceptions of ECE.

Because Grace provided the family daycare in her house from 6 am to $6 \mathrm{pm}$, five days a week, her community more often considered her as babysitter. Yet, Grace had never 
thought about her role for children as simply a caregiver. If she had, she probably would not have attended junior college to get an Associate Degree in Early Childhood Education and renewed the license of her family daycare center every three years. Grace was proud of herself because she believed that she took her role as a teacher seriously and acted professionally. Thus, the babysitter image offended her and affected her confidence as a facilitator in the classroom. Ashley explained the differences between babysitting at home and teaching in a preschool setting:

Baby-sitting is putting children in front of TV while you read a book or just watch them. Teaching young children is a lot different from that. Teachers know children's developmental process and based on these, we are taking care of children, and providing environments for what they can do, so that children can learn and experience a lot of things they cannot do at home because these activities would take a lot of time, space, and energy,causing parents' inconvenience.

The statement, providing learning environments for young children, shows the teaching role of preschool teachers as opposed the role of a babysitter. Preschool teachers put a lot of effort into developing activities to encourage learning and to assess individual children's physical, social, and cognitive development. My observations with the seven preschool teachers verified this statement. This is one of Ashley's classroom observations:

(8:45 am) Ashley was interacting with several children. Today, Ashley put some dot-markers and papers on one table (art area). On a sensory table, she put rice; last time, children played with beans on the sensory table. She prepared papers with several holes and strings in a manipulative area. She told me that they are going to make an Easter Basket. Easter is one week later, so they are going to prepare for the holiday even though they don't have any special event in this center (this is a church-based center). Whenever a child came in with a parent, Ashley approached the parent and child and said hello to them. Most of the time, Ashley had a short conversation with the parents. Right after the parents left, Ashley approached any child who did not find an interesting activity yet, and guided him/her to do new activities she provided today.

(9: $27 \mathrm{am})$ Ashley hung some Easter Baskets on the ceilings. Depending on the wishes of the children, they could take the basket home or let Ashley hang it in the classroom. Ashley softly asked individual children what they wanted.

This observation demonstrated the teaching materials and activities newly displayed by Ashley and her interaction with children and their parents. The observation shows the role of a preschool teacher as an administrator. As these preschool teachers are depicted from the previous observation, preschool teachers needed to manage the class in every aspect: corresponding with parents, interacting with children, providing a learning environment, and fostering children according to their personal needs. In spite of these differences between babysitters and preschool teachers, the socially biased conception of preschool teachers is deeply rooted as Ashley explained:

People, even parents, don't realize how an infant/child develops and they just don't understand that we preschool teachers learned about it and consider it in our teaching. They don't know how important our role is to child development.

This comment highlights the difference between babysitter and preschool teacher in knowledge of child development. Florence, who had been working in a preschool setting for 36 years, also supported Ashley's point of view:

I don't think the general public or parents really understand what the early childhood education profession is. I don't think they understand CDA (Child Development Associate credential). This 12 credit hour certificate program mainly focuses on early growth and development. To become a preschool teacher, you (general you) have to take these classes at least. So, we know how important children's development is and how interrelated their development and learning needs are. However, people don't understand how important this age is because they don't know how much children can be changed in the early years.

Florence explained that the basic qualification for being a preschool teacher is to possess knowledge and information on child development. Since Florence has had experience in staff development as a director, she emphasized the importance of acquiring the CDA degree, which stresses child development. Both Ashley and Florence agreed that the public, especially parents, do not recognize that becoming a preschool teacher requires knowledge-based caring for children's whole development. Although both of them made similar points, their discussion was a bit different. Ashley discussed the importance of organizations and administrations whereas Florence emphasized the importance of knowledge towards child development. The women lamented this lack of public understanding of the genuine meaning of educating young children.

\subsection{Teaching instruction-Content vs. Experience}

Engaging children in learning and helping them to find their own interest are the most important principles of early childhood education (Katz \& Chard, 2000). Yet, it is paradoxical that, according to this idea of education, preschool teachers are definitely not professionals because they don't teach subject knowledge. Considering early childhood education as a readiness for school to learn the 3Rs results in disregarding the importance of education for young children. This misconception of early childhood education downplays the role of the preschool teacher for children's learning. Because those who are not familiar with early childhood education do not see that preschool teachers deliver knowledge and teach subjects, they regard teaching young children as nothing but caring. However, Joan had a different perspective on preschool teachers:

Teaching younger kids requires special talents and patience to do this job. So I can see myself as professional, 
because I can do this job with a good attitude. I can accomplish what I have to do, and I have my goals about what I need to do and I do it! That's why I can consider myself as professional as well as other preschool teachers, because I do what I need to do appropriately.

In Joan's view, early childhood education teachers are very patient people because they must manage groups of young children and foster young children in productive learning activities. According to Piaget, two to seven year old children on average are located in a preoperational developmental stage. The cognitive development of children in this stage is still influenced by perceptual activities so that their actions can be internalized via representational functions, but their thought is still tied to perception (Wadsworth, 1996, p. 66). Understanding and teaching young children who learn in sensor motor and preoperational ways requires special training and patience. Because Joan knew about child development and was practicing her knowledge, she considered herself as a professional.

Joan's example clarifies how the female preschool teachers in this study suffered from a conflict between public images of preschool teachers and their actual roles of preschool teachers. As these preschool teachers reported, the misunderstanding of early childhood education distorted the images of preschool teachers equating their roles to those of babysitters. Teaching young children has been historically considered a woman's job from its inception (Goldstein, 1997), and this idea of women's work has prevented people from challenging the image of preschool teachers in a patriarchal society. In a patriarchal society men define women's nature and their work, and women's work could never achieve professionalism, which was reserved for men. Women teachers' efforts in the classrooms have been seen as women's work, which is therefore inferior to the work done by men (Carter, 2002). The roles of good mothers has also never been associated with professional in masculine society because as Alice Kaplan explains it, "if teaching is natural, it must be "too easy to be of much value" (Munro, 1998, p.3).

These female preschool teachers demonstrated what preschool teachers' roles should be like in practice. In particular, the teachers' interactions with children were elaborated and articulated so that the female teachers could handle young children. Preschool teachers' professional ways of teaching young children provide finely organized learning environments where children can investigate their own world. Unless the misunderstanding of the teachers' role in early childhood education is corrected, female preschool teachers will continue to struggle for professional recognition. The following theme explores how the lower socioeconomic status of preschool teachers contributes to the image of semi-professionalism of preschool teachers.

\subsection{Socioeconomic Status and Babysitting}

Teachers of younger children are the lowest-paid, least valued, and lowest-status workers in the social structure, because they exercise little control over the profession and implement few meaningful values in a patriarchal society (Rensenbrink, 2001; Weiner \&Kallos, 2000). The lower salary demonstrates their lower social status as preschool teachers. Some female preschool teachers in this study cannot afford to their independent living. Joan with a college degree in Elementary Education major worked in a head start program and was living with her mother because she could not afford to pay her rent by herself:

I can't live by myself with this salary because I have to pay my student loan, credit card bill, and a car payment. So, I can't afford my own place and I live with my mother.

According to Katz (2004), average wages for preschool and childcare are about $\$ 16,000$ per year. These informants' salaries varied depending on the type of childcare center (private or public), the years of teaching experience, and degree of Teacher Education (college degree or certificate). These preschool teachers definitely make less money than elementary school teachers. The reality of a low salary forces some female preschool teachers to live under extreme hardship. Thus, Joan had to receive some support from her family. Even Ashley, who had worked in the same preschool for 12 years, stated that after her family found out how much she made as a preschool teacher they expressed their disbelief: how she could live on that salary. A preschool teacher cannot be a breadwinner for a family. Among these seven informants, five were married and their incomes were not the primary financial support of their family. They all agreed that they were lucky that their husbands made enough money so they could remain as preschool teachers. Emma explained:

If I were a single woman, I'd have to have a roommate or probably live with my mom (Laugh), because I could not support myself as a preschool teacher. I make less than 20,000 a year, so I owe more money than I can make now. Fortunately, my husband makes enough money, so I can do what I love to do, which is teaching young children.

Joan fits Emma's hypothetical example: the single preschool teacher living with her mother because of low income. Another teacher, Florence, explained that another important reason for her to choose becoming a preschool teacher was because she did not need to worry about finances for her family because of her husband. Florence added:

Because my husband always made good money, I just decided to be a preschool teacher and I felt "this is where I was needed," so I just decided to stay in preschool.

The financial support Florence received from her husband influenced her to willingly choose working with young children. Thus, the financial support of husbands plays a critical role for a woman who wants to be a preschool teacher. In a patriarchal society women are expected to depend upon their husbands financially. The inadequate income of preschool teachers is the result of this social belief and also appears to keep them within the established system. Female teachers who do not have a primary income from husbands have to find a secondary financial source to sustain their profession. Jane explained:

Unfortunately, there are some teachers here (in her center) 
who have to be babysitters because they did not make enough money for a living. That's not right. They babysat for not extra money, but enough money. In my case, I can concentrate on my job I like, because my husband makes pretty comfortable money for a living. I am very lucky because I was not put in that position. However, my husband would like to retire after 7 years, and it would be nicer if I would be making a little bit more than now.

Some preschool teachers who are economically stressed have to work more as babysitters to make enough money for a living. Preschool teachers never officially offer this service, but they often accepted the request because of financial reasons. Parents and even preschool teachers take preschool teachers' babysitting for granted. Though none of the preschool teachers viewed their role of teaching as babysitting, the fact that some preschool teachers have to babysit for a living probably confirms the babysitter image of preschool teachers in society. Although they refuse to be seen as a babysitter, babysitting for children in their classroom is an unfortunate but easily available resource to solve their financial problems. Thus, the majority of preschool teachers claim that their role of preschool teacher is not equivalent to babysitting, but nobody censures them for babysitting for financial reasons.

\subsection{High Turnover Rates and College Degree}

The low income earned by the preschool teachers caused other serious problems, encouraging non-professionalism in early childhood education. For example, one of the main problems is teachers' high turnover rate. Joan explained:

That's why Head Start has such a high turnover --because for preschool teachers, it's easy to find a job in which the payment is more than that of preschool teachers and that's why there is high turnover. Who can blame them?

According to Spencer (1986), the reason for high dropout rates among first-years teachers is that they realize that better pay and more prestige are found in other fields. According to Florence, the Head Start program has good health benefits and good retirement benefits compared to other private childcare centers, so she tried to go back to Head Start, but, there was no available job at that time and she stayed in a private preschool. However, Joan, who still taught in a Head Start program, claimed that there is high turnover even in that program, which is funded by the State and federal government. This high turnover rate causes serious impact on preschool children and teachers. Ashley explained:

Yes, there is a high turnover in this field and it causes a serious influence on children. Some of children like infants and toddlers were so affected by teachers' changing because they need a primary caregiver for their emotional development, so teachers need to consistently work for children... but, it's hard. Moreover, if someone quits at the middle of semester and a new teacher comes in; all the teachers have to consider the staff changing. That's complicated, you know.

Ashley points to a major issue in professionalism in early childhood education. If preschool teachers easily quit in a short period, they cannot practically play a teachers' role and build strong relationships with children. Regarding the influence of staff changing on children's emotional development, recent studies discover that children who experienced frequent changing of a primary caregiver in daycare centers show serious anxiety (Katz, 2004; Stevenson, 2004). Frequent changing of teachers negatively influences other teachers as Ashley pointed out. Whenever a new teacher came in, the remaining teachers needed to train the new staff in what to do and how to interact with children in the classroom, because every classroom had different daily schedules and planned different activities based on lead teachers' curriculum and teaching styles. However, the lead teachers did not put much effort into new staff training because they were cynical about how long the new teachers would stay with them. They did not want to waste their time on new staff training, which might have to be repeated over and over.

The teachers have also suffered from another aspect of teacher qualification in terms of lower payment: their college degree. As a lead teacher, Jane had a Bachelor's degree in Early Childhood Education. However, her college degree did not increase her salary even though ECE encouraged acquisition of a college degree to become a lead teacher. Jane stated what bothered her with the relationship between her degree and income:

I make nothing here. What do I make a year? $\$ 24,000$ a year as a seven years experienced teacher! I have a college degree, which is the same degree a lot of public school teachers have, and probably I work longer hours than public school teachers do, but I don't make money like them. We have salary discussions all the time, but the administrators tell us, "Don't even HOPE to get what public school teachers do." What is it? Isn't it sad?

According to the National Education Association (1983), first year teachers could make $\$ 3500$ less than a starting salary for a college graduate in business administration $(\$ 16,200)$, which was the next lower-paying profession (Spencer, 1986).This statistical poll indicated elementary through high school teachers' salaries in average. The salary of early childhood education teachers is a lot worse than that of elementary or high school teachers. Even though preschool teaching profession requires a college degree for becoming a lead teacher, her salary does not reflect this qualification at all. It seems meaningless to acquire a Bachelor's degree in Early Childhood Education to become a preschool teacher in this society money-wise. This tendency causes a serious professional problem which is loss of qualified and experienced teacher which is also related to high turn over rate issues. Not surprisingly, this profession is not like other levels of school system regarding health insurance and retirement benefits. Florence has been working in ECE for over 36 years, but she confessed that she did not want to recommend this profession to young people:

I'm looking back now, and I kind of regret remaining a preschool teacher. 
I told my daughter and other girls I know, "Go to be an elementary school teacher!" I mean if you are single, you cannot support yourself with this salary. The situation of an elementary school teacher is much better because obviously they have more salary and benefits.

Throughout all the interviews and observation, Florence showed her passion for early childhood education and proved why and how she could stay in this profession for three decades. However, regarding the financial issue, even she regretted becoming a preschool teacher, not because of the job description of preschool teachers, but because of lack of financial support.

Interestingly, even though these teachers suffered and struggled with the social misconceptions of early childhood education and its teachers, they had shown a long-term commitment to this field. Although this profession did not reflect their efforts and qualification as a teacher in their salaries, they voiced that it did not mean that they loathed and undermined the early childhood education field. Jane, who sought her Bachelor's degree in Early Childhood Education at age 40 s, described:

I did not think about the money when I chose this field, because I knew this is what I wanted to do and I did not have to support myself... If I decided to make money I would have been gone back to school or probably find a job I could make more money. Sometimes, I felt guilty because I haven't contributed financially to my family (Laugh), but I want to be here (teaching preschool).

Despite negative influence contributed from the lower income's, Jane's passion for teaching young children was strong enough to overcome the financial hardship. Emma, who desired to get a job in a public elementary school, expressed:

If I can pick either early childhood education or elementary in my master's program, I will probably pick ECE because that's where my heart is. I love children. I know, I want to make different statements and it sounds cheesy and fake, but you know I really do! It's a very attractive job for me. (pause) I asked to my husband, if I really like this job, can I stay even though I cannot make more money? He said it's okay if I like it; I have to do what I love to do. I really appreciate his support for my job even though I do not make good money.

Emma stated earlier that even after she could have taught in a public elementary school, she would like to teach young children like kindergarteners or first graders. Her attraction to teaching young children persevered even though the financial problem of this field was more serious than she thought. Emma showed her enthusiasm toward this job and it made her sustain in this tough field. It is important to acknowledge that these preschool teachers showed strong a commitment to their profession. While the financial situation for preschool teachers made them consider shifting to another field, it did not indicate that preschool teachers overlooked the importance of early childhood education and their role within it. On the contrary, these female preschool teachers evidently recognized the significance and value of early childhood education. What these preschool teachers would value was fair payment for their professional labor that will make preschool teachers regarded as professionals in society.

\section{Discussion}

Early Childhood Education, where the majority of teachers are women, is often regarded as semi-professional in society (Prentice\& Theobald, 1991). As identified in this study, female teachers are suffering from perceptions of the low status of professional knowledge in education, and from the lack of respect for, and control over, education disciplines due to the very fact that this is a female dominated field. However, through these teacher life history interviews, seven female teachers explained how they confronted the social misconception of preschool teachers and developed a different conception of being teachers of young children and their professionalism as women teachers. Particularly, these teachers did not exaggerate the role of caring in teaching young children, nor diminish it in the role of preschool teachers' occupational identities. The informants did not consider the teachers' ability of caring related to their professionalism. Instead, they emphasized three elements of being professionals in Early Childhood Educational field: dedication, passion, and commitment. These teachers believed that dedication and commitment to ECE are more critical elements for shaping their professionalism. Moreover, seven women preschool teachers strongly stressed that their passion for educating young children was the main motivation for becoming professionals in this field.

In society, women in the field of education are still a minority in terms of social status to men in the same workforce (Biklen, 1995). Thompson states that "although individual women may gain access to power, women as a group in society will not be able to achieve parity with men without fundamentally changing the system" (2003, p. 29). The feminization of teaching not only means the gradual increase in the numbers and proportions of women teaching in most school systems, but also embodies female teachers' low status and payment within patriarchal systems (Prentice \&Theobald, 1991). That is, as women work in schools, the traditionally honorable career, teaching, becomes a lower professional level in patriarchal society for that very reason.

However, even though this feminization of the teaching profession undervalues it, we cannot ignore the large impact of women's participation in this profession. Munro (1998) states that because teaching is a gendered construction, the teaching profession provides an excellent opportunity to explore the process of how gender ideologies become naturalized as well as how gendered norms are contested in the daily lives of women teachers. Weber and Mitchell (1995) admit that even though female teachers are not romanticized in their actual day-to-day teaching, the text of female teachers' identities cannot be separated completely from the 
texts of gender, love, and sexuality, which are created in popular cultures such as soap operas, magazines, novels, advertising, tabloids, and more (p.110). The emerging problem in this social and cultural context is that although these kinds of images of female teachers are inappropriate for the teachers' personal and occupational identities, there are no other ways for female teachers to express their own identities. Munro suggests, "listening to women's voices, studying women's writing and learning from women's experiences has been crucial to the feminist reconstruction of our understanding of the world" $(1998$, p. 6). Through the process of communicating with teachers, the personal voices of women teachers and the descriptions of their daily lives as teachers have been aired and revealed both the naturalization and contestation of gender expectations.

\section{Conclusion}

The combination of early childhood education and feminist perspectives is the significance of this study. Since female teachers have mainly occupied preschool teaching positions, it was natural to think that teachers of young children are female. Interestingly, there is plentiful research on male teachers that explores their social and self-perceptions rather than that of female teachers in the field of ECE (Barnard, et al; 2000; Clyde, 1994; Shaham, 1991; Skelton, 2003; Weiner \&Kallos, 2000). These researchers explained that because ECE is a female dominated profession, it is important to know how male teachers in this field construct their identities among the majority of female colleagues and within social biases: how men could work with young children (Shaham, 1991). The authors of these studies believe that showing why and how men build their personal identities as preschool teachers would help early childhood educators to recruit more male teachers for providing balanced gender role models for young children (Barnard, et al, 2000; Clyde, 1994; Shaham, 1991; Skelton, 2003).

The history of early childhood education shows that the teachers of young children have always been women, and this fact has been taken for granted over the centuries in America. If it is assumed that feminism is about women and the stories of their relationship with society, it is not understandable why there is a chasm between feminist scholarship on education and the literature on female teachers in early childhood education. Both feminism and early childhood practices have traditions of transformative agendas (Goldstein, 1997; Rensenbrink, 2001). Their practices of advocacy for children, women, and families have often been targeted at similar issues, but they have existed in parallel rather than overlapping efforts (Goldstein, 1997; Hauser \&Jipson, 1998). Therefore, the separation of educational feminism and early childhood education feels awkward and artificial. In this perspective, using feminist perspectives to analyze female preschool teachers' identities seem particularly appropriate when looking at the identities of early childhood educators (Hauser \&Jipson, 1998). As revealed in this study, feminist perspectives can illuminate undiscovered or hidden identities of female preschool teachers and the impact they have upon their professionalism.

Not withstanding, we need to consider how women teachers in this profession are thinking about themselves as teachers and women and this study is the first step in this direction. It seems that male teachers in ECE are treated as a minority, and this is why they receive more attention regarding identity formation and the development of social perception; in turn, there is little research that explores the identities and perceptions of female teachers for young children. This tendency might support the assumption that women have more power over men in early childhood educational field, because most preschool teachers are women. When contextualized in the broader social reality, as explored in this study, this power is only in quantity (number of bodies) and not quality of authority. Just because of the fact that most teachers in early childhood education are women, women teachers do not often have opportunities to discover their needs and identities through research and their voices are thus ignored.

\section{REFERENCES}

[1] Acker, S. (1989). Rethinking Teachers' Careers in Acker (Ed.). Teachers, Gender \& Careers. Philadelphia, P.A.: the Falmer Press.

[2] Ayers, W. (1989). The good preschool teacher: Six teachers reflect on their lives. New York, NY: Teachers College Press.

[3] Black, E. (1989). Women's work in a Man's World: Secretarial Training in a College of Further Education. in Acker (Ed.). Teachers, Gender \& Careers. Philadelphia, P.A.: the Falmer Press.

[4] Barnard, C., Howingh, L., Nezwek, M., Pryor-Bayard, D., Schmoldt, J., Stevens, J., Sturrus, W., Wabeke, S, \& Weaver, L. (2000). Recommendations for improving the recruitment of male early childhood education professionals: The female viewpoint. Unpublished master's thesis, Grand Valley State University, Allendale, Michigan. (ERIC Document Reproduction Service No. ED 440759).

[5] Biklen, S.K. (1995). School work: Gender and cultural construction of teaching.New York, NY: Teachers College Press.

[6] Carter, P.A. (2002). Everybody's paid but the teacher: the teaching profession and the women's movement. New Work, NY: Teachers College, Columbia University.

[7] Carter, K., \& Doyle, W. (1996). Personal narrative and life history in learning to teach. In Sikula, J., Buttery, T.J., \& Guyton, E. (Eds.) The Handbook of Research on Teacher Education. (pp. 120-142). New York: Macmillan.

[8] Clyde, M. (1994, March-April). Men in Early Childhood: What do women think about it? Paper presented at meeting of 
the Association for Childhood Educational Study Conference, New Orleans, LA. (ERIC Document Reproduction Service No. ED 370711).

[9] Dhunpath, R. (2000). Life history methodology: "narradigm" regained. Qualitative Studies In Education, 13(5), pp.543-551.

[10] Goldstein, L.S. (1997). Teaching with love: A feminist approach to early childhood education. New York: Peter Lang publishing.

[11] Glaser, B., \& Strauss, A. (1975). The discovery of grounded theory: Strategies for qualitative research. Chicago: Aldine.

[12] Goodman, J. (1988). University culture and the problem of reforming field experiences in teacher education. Journal of Teacher Education, 39(5), pp. 45-53.

[13] Goodson, I.F. (1992). Studying teachers' lives. London: Routledge.

[14] Grumet, M. (1981). Pedagogy for patriarchy: the feminization of teaching. Interchange, 12(2-3) pp.165-184.

[15] Gubrium, J.F. \& Holstein, J.A. (1997). The New Language of Qualitative Method. New York, NY: Oxford University.

[16] Hauser, M. E., \&Jipson, J.A. (1998). Intersections: Feminisms/Early Childhoods. Rethinking Childhood vol. 3. New York: Peter Lang Publishing, Inc.

[17] Hawthorne, W. (1994). What's life got to do with it? The interface of professional and personal development. Australian Journal of Early Childhood, 19(3), pp.45-48.

[18] Katz, L. (2004). When does $\$ 1.00$ equal \$7.00? In Glickman, $\mathrm{C}$ (Ed.). Letters to the next president: what we can do about the real crisis in public education. New York, NY: Teachers College Press.

[19] Katz, L.G. \& Chard, S.C. (2000). Engaging Children's Minds: the Project Approach 2nd edition. Stamford, CT: Ablex Publishing Corporation.

[20] Merriam, S.B. (1998). Qualitative research and case study application in education. CA: Jossey-Bass by John Wiley \& Sons, Inc.

[21] Middleton, S. (1989). Educating Feminists: A Life-History Study. in Acker (Ed.). Teachers, Gender \& Careers. Philadelphia, P.A.: the Falmer Press

[22] Munro, P. (1998). Subject to fiction: Women teacher's life history narratives and the cultural politics of resistance. Buckingham, Philadelphia: Open University Press.

[23] Prentice, A., \& Theobald, M.R. (1991). The historiography of women teachers: A retrospect. In Prentice, A., \& Theobald, M.R.(Eds.), Women who taught. (pp. 3-33) Toronto, Canada: University of Toronto Press.
[24] Rensenbrink, C. W. (2001). All in our places: Feminist challenges in elementaryschool classrooms. Maryland: Rowman\& Littlefield Publishers, Inc.

[25] Saracho, O. N. (1993). Preparing teachers for early childhood programs in the United States. In Spodek, B. (Eds), Handbook of research on the education of young children. (pp. 421-426) New York, NY: Macmillan Publishing Company.

[26] Shaham, D. (1991). Male teachers in early childhood education: Self \& social perceptions. Unpublished master's thesis, Bank Street College of Education, New York, New York. (ERIC Document Reproduction Service No. ED 366 417).

[27] Skelton, C. (2003). Male primary teachers and perceptions of masculinity. Educational Review, 55 (2), pp. 195-209.

[28] Spedek, B., Saracho, O.N., \& Peters, D.L. (1988). Professionalism, semiprofessionalism, and craftsmanship. In Spedek, B., Saracho, O.N., \& Peters, D.L. (Eds), Professionalism and the early childhood practitioner. (pp. 3-9) New York: Teachers College Press.

[29] Spencer, D.A. (1986). Contemporary women teachers: Balancing school and home. White Plains, NY: Longman Inc.

[30] Stevenson, S. (2004, April). Understanding staff turnover in ECE: Finding new solutions. Paper presented at the meeting of the American Educational Research Association, San Diego, California.

[31] Thompson, A. (2003). Caring in context: Four Feminist theories on gender and education. Curriculum Inquiry 33 (1) $9-65$.

[32] Vuorikoski, M. (2001, April). Constructing personal professional Identity during teacher education. Paper presented at the meeting of the European Society for Research on the Education of Adults (ESREA) Gender Network Conference, Geneva, Switzerland, (ERIC Document Reproduction Service No. ED 464897).

[33] Wadsworth, B.J. (1996). Piaget's theory of cognitive and affective development: Foundations of constructivism, Fifth Edition. White Plains, NY: Longman Publishers USA.

[34] Weber, S., \& Mitchell, C. (1995). That's funny, you don't look like a teacher: Interrogating Images and identity in popular culture. Philadelphia, PA: The Falmer Press, Taylor \& Francis Inc.

[35] Weiler, K. (1992). Remembering and representing life choices: a critical perspective on teachers' oral history narratives. Qualitative Studies in Education, 5 (1), 39-50.

[36] Weiner, G., \&Kallos, D. (2000, April). Positively women: Professionalism and practice in teaching and teacher education. Paper presented at the meeting of the American Educational Research Association, New Orleans, LA. (ERIC Document Reproduction Service No. ED 441 799). 